\title{
CHAPTER II
}

\section{Sumba and the state}

Writing about politics, means writing about the state. What 'the state' actually is, however, is a matter of ample academic debate. In that debate, Max Weber's original explanation is usually taken as the point of departure for discussion. He defined a state as 'a human community that (successfully) claims the monopoly of the legitimate use of physical force within a given territory' (Weber 1946:1). The legal connection of state to a territory, its monopoly of violence, and the coherence of the organization, have all been debated and questioned in light of actual practices (Van Klinken and Barker, forthcoming). Sumba is part of the Indonesian nation-state, and the state officials who govern this island are both part of the bureaucratic hierarchy on Sumba, and subordinates within a nation-wide state organization with its centre in Jakarta. The state connects Sumba to other parts of Indonesia. The state's monopoly of violence does not make much sense on Sumba, where the armed forces and police are small in number and where private violence is a traditionally common way to deal with disputes, thieves, and murderers. Aradhana Sharma and Akhil Gupta (2006:5) argue for an anthropological approach to studying the state 'focusing on two aspects for analytical clarity: (a) the practices [of the state officials], and (b) the representations of the state'. Such an approach leads to 'understanding the state as a multilayered, contradictory, translocal ensemble of institutions, practices and people in a globalized context' (Sharma and Gupta 2006:6). With this abstract model in mind, I will describe the state on Sumba, in a much more concrete way.

Most readers have probably never been to Sumba, but they may be familiar with other islands in Indonesia, or with other places in the world where processes of democratization are underway. Comparisons within the national framework of Indonesia designate Sumba (or the whole province Nusa Tenggara Timur) as poor, isolated, backward, predominantly Christian, traditional, and lacking resources with low agricultural and economic potential (Corner 1989:197). Indicators that show per capita averages are very useful for comparison with general levels in other regions of Indonesia. Yet, local politics are focused on local differences and interests, and these are not solely explained by island-wide characterizations. The first part of this chapter will 
provide a more sophisticated characterization that differentiates between areas in Sumba, between life in rural areas and life in town, and between poor and wealthy. What are the social and economic interests on which Sumbanese politics are based and how are they utilized?

The physical, social and economic characteristics of Sumba generate the context in which the state was formed and still operates. The image of the state depends on the historical forces that shaped it, which are specific to each particular period. In the second part of this chapter, I will explain about the connection between state formation, Christianity and modernity in Sumba. The state as an idea was composed in the past, but at present on Sumba it does not refer to images of nation-state; instead it is associated rather vaguely with general opportunities for upward mobility, and more concretely imagined as a vast complex system (or institution) of secure employment and additional material benefits. Sumbanese want to become part of this complex system. The way to achieve this is to accumulate capital, in the sense Pierre Bourdieu used the concept (1986), namely, cultural, social and economic capital, and use these to move upward toward positions from which the state's resources can be managed. Umbu Djima's life history in this chapter will explain and illustrate this. As a son of nobility he was selected for the Dutch Christian missionaries' school. His family's wealth enabled him to further his education. His career in the bureaucracy started with a successful period in the provincial capital Kupang. He moved to Jakarta to be member of the national parliament representing Golkar. From 1985 to 1995 he was West Sumba's bupati, and after retirement from state service he started a new career in the Protestant Christian Church. This biography demonstrates how the state can be utilized as a medium for personal career.

At the present, the state is the most important source of salaried employment on Sumba and a main sector of the island's economy. Local politics are about distribution of the state's resources and strategies to obtain government positions. Yet, the state is more than just jobs and budgets. Looking closely at everyday practices of state officials show what the state is and how it operates. For many people the state appears most prominently in many bureaucratic procedures, in salaried employment, and as a flow of funds that finances building and infrastructure projects. In the last part of the chapter, I describe the state on Sumba as a system of bureaucratic procedures and as an economic sector.

The chapter ends with a section on social cleavage in Sumba, between those who control the resources of the state - jobs, funds, decision power, legislation and legitimized violence - and those who have little or no access to those resources. In that last part of the chapter I introduce the term 'political class' to refer to the former group and 'tani-class' to refer to all those who are excluded and who refer to themselves when asked about their occupation as 
'just farmer' (tani). In between these two classes, there is a category of people who want and try to be part of the political class, but who remain excluded. They may be well educated, or wealthy or of high social rank, but they lack the minimum combination of social, cultural and economic capital that is required to enter the political class.

\section{Sumba: geography and subsistence}

Sumba is an island, located $400 \mathrm{~km}$ east of Bali, south of Flores and northwest of Australia (see map). It is part of the outer arc of the Lesser Sundas. Sumba is a relatively large island of 11,500 square km, 200 kilometres long and from 36 to $75 \mathrm{~km}$ wide. There are two airports: Tambolaka in West Sumba in the northern coastal zone west of Karuni, and Mau Hau close to Waingapu. Between three and five times a week there are flights to and from Bali and Kupang. The flight in a forty-passenger aircraft takes about one and a half hours to Bali and a one-way fare is equivalent to half a local schoolteacher's monthly salary. Travelling by sea is cheaper. There are ferries to Kupang on Timor and to Ende on Flores. The main harbour of the island is in Waingapu, the capital of East Sumba. The second harbour is Waikelo, north of West Sumba's capital Waikabubak.

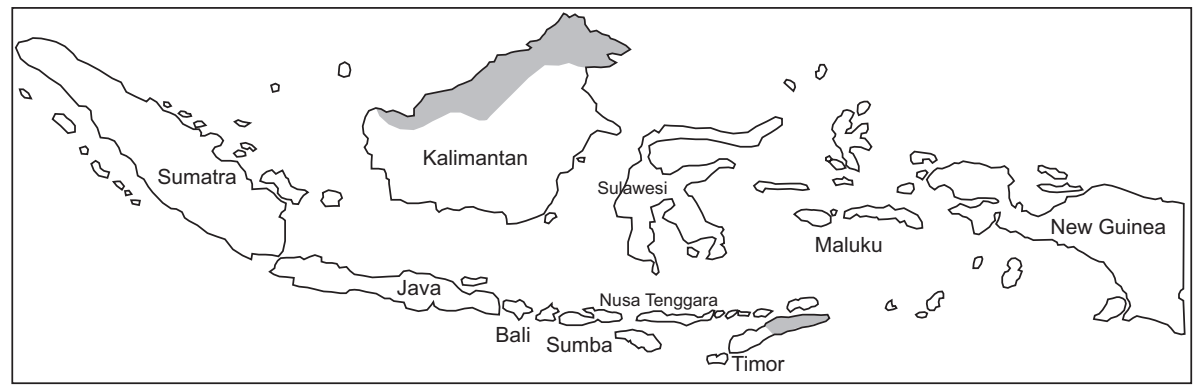

Map 2.1 Sumba's location in Indonesia

Most Sumbanese never travel to other islands: their life is on Sumba, and the cost of travelling is too high. For the wealthiest fraction of the tourists, Sumba's isolation is an asset that can be enjoyed in the luxurious resort of Nihi Watu. ${ }^{1}$ The lowest room rate per night is equivalent to three months 
salary of a local teacher. Nihi Watu tourists can embark on an excursion to a 'traditional village' and leave their completely closed resort for fifty dollar per hour. Sumba is 'far and isolated' from a foreign or Jakarta-perspective, but those who can afford the journey can go there fairly easily.

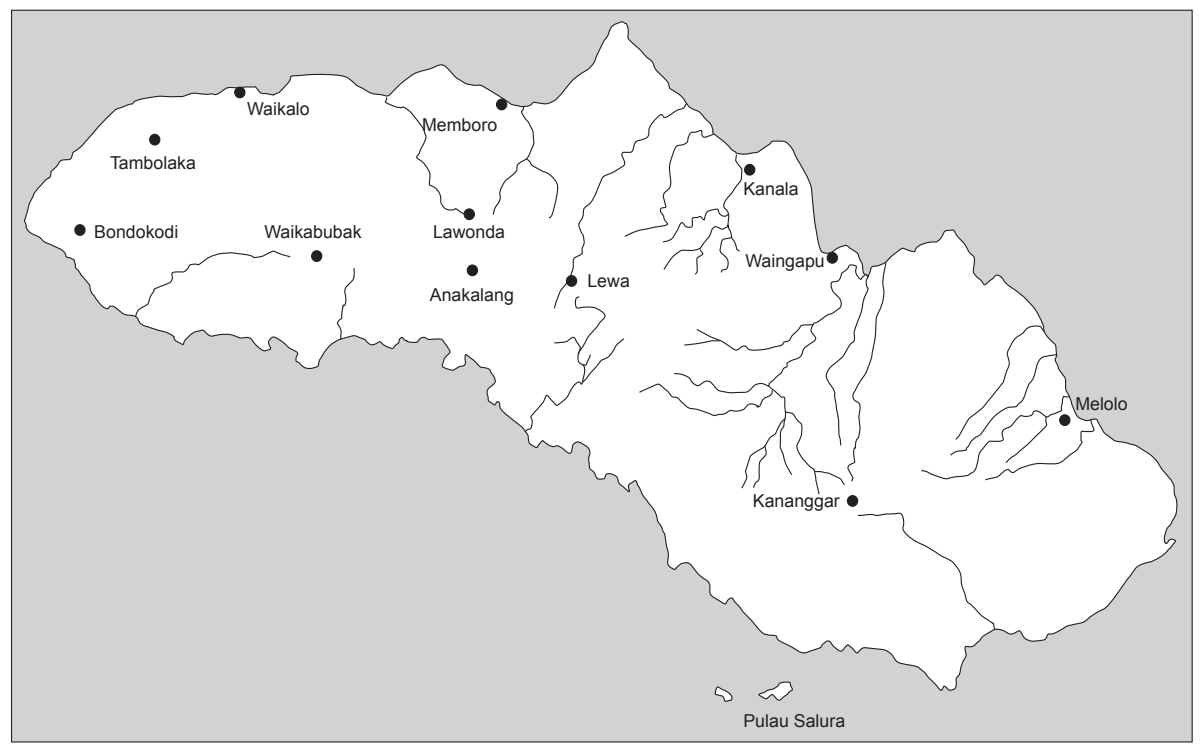

Map 2.2 Sumba

Sumba is not as fertile as the volcanic islands of Indonesia. The island is a fragment of the Australian continent that separated from the main continental mass 20 million years ago (Fowler 1999:107). The soil is composed of various types of limestone and uplifted coral reefs. Eastern Sumba consists of hilly and low-lying grassland, coastal terraces and limestone plateaus. When travelling westward from Waingapu, one climbs up to the hills, and in the dry season the view from these hills over East Sumba resembles images of the Grand Canyon in America.

The central part of the island consists of limestone plateaus, undulating hills and deep river valleys. The western region features terrain from forested uplands crisscrossed by seasonal creeks to coastal lowland terraces (Fowler 1999:108). The coastal zone is only a few kilometres wide, with a hot and dry climate. The eastern part of the island is also hot and dry, due to the southeast trade winds blowing off the Australian continent. This part of Sumba has a long, dry season, between April and November. In November the northwest monsoon brings rain to the island. Rainfall varies over the island, with the 
lowest amount in East Sumba and the coastal zone, and the highest amount in the mountainous areas of West Sumba. In Lawonda, Central Sumba, where the village described below and in chapter IV is located, rainfall was about $1500 \mathrm{~mm}$ annually, with a dry season from May to October.

Between the two plains of Lewa and Anakalang, a wildlife sanctuary surrounds Wanggameti Mountain, with its highest peak at 1,125 metres above sea level. It is famous for its bird life, including nine endemic species, of which the Citron-crested Cockatoo (Cacatua sulphurea citrinocristata) is best known. ${ }^{2}$

Differences in landscape and rainfall determine the type of subsistence activity in agricultural societies. East Sumba - outside the capital Waingapu - is sparsely populated. Traditionally it was the area for keeping livestock in addition to practicing subsistence agriculture. The nobility owned large herds of horses, water buffaloes and cattle, whereas the lower ranks would herd the animals and work on the land to cultivate food crops. In West Sumba population density is much higher. The landscape and climate there make possible a more intensive type of agriculture in which cash crops have become increasingly important.

Sumbanese love their island, but life there has always been hard. Land is plenty, but the soil is not very fertile. Growing crops on the hillsides is hard work with only very modest yields. The wet paddy fields in the valleys provide at better living, but only the wealthier inhabitants have access to this type of agriculture. Parts of the cultivated fields are not close to a main road, preventing the use of hand tractors or other machines. Nonetheless, agriculture has always been the main source of living on Sumba. It comprises all the activities that support subsistence in the rural areas of the island: growing food crops for consumption, keeping small livestock around the house for meat and eggs, keeping cattle and buffaloes for ceremonial purposes and for tilling the land, keeping horses as a means of transport and because they are the most important part of bride's dowery. Sumbanese subsistence also involves gathering activities: fishing, cutting grass for thatching roofs, chopping trees in the forest for building material, gathering firewood, digging wild roots and tubers when food is on short supply, catching or hunting wild animals for sport, pest control and additional protein rich food. All these activities require significant labour, and sadly the return on labour is low. Natural phenomena like droughts or flooding and pests, especially locusts in the last decade, have made life in the rural areas even more difficult.

When Sumba was incorporated into the colonial state of the Dutch East 


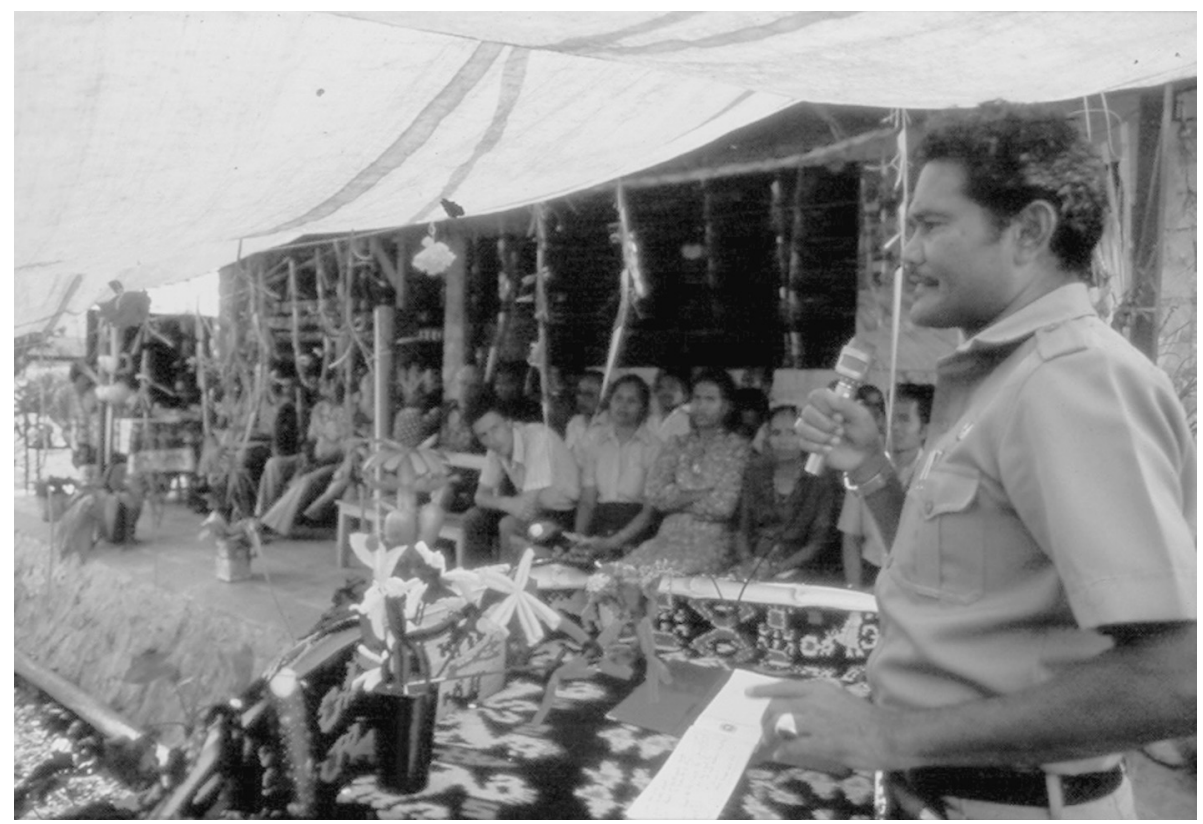

Umbu Djima gave a speech at Propelmas in 1988

Indies at the end of the nineteenth century, the government started to levy taxes on the island's population. Since then, the need for money has continuously increased: to buy products that can not be obtained trough barter exchange (for example kerosene, sugar, soap), to pay school fees, to pay for transport, to buy luxury goods, to pay for medical treatment and so forth. In my book The Uma economy (Vel 1994) I elaborated on the strategies adopted by the rural population in Sumba to meet their monetary needs. The most salient of those strategies was to get a close relative employed in a wage earning position and to share the monetary income with a larger group in return for food, labour and ceremonial services. These informal networks between rural and urban Sumbanese, between younger and older generations, bring food and domestic labour to town and return money and luxury goods to the villages. The urban professionals and their families can rely on their village-partners for organising ceremonies such as weddings and funerals in the ancestral village, whereas the villagers have a basis in town where their children can go to school and they can stay if they need medical care.

Compared to the other areas of Indonesia the province of East Nusa Tenggara (Nusa Tenggara Timur, NTT), of which Sumba is a part, is considered a poor, 
Table 2.1 Sumba in figures and quantitative comparison*

\begin{tabular}{|c|c|c|c|c|}
\hline Indicator & $\begin{array}{l}\text { West } \\
\text { Sumba }\end{array}$ & East Sumba & $\begin{array}{c}\text { Nusa Tenggara } \\
\text { Timur }\end{array}$ & Indonesia \\
\hline $\begin{array}{l}\text { Population } \\
2005 \\
x 1000\end{array}$ & 404 & 206 & 4,260 & 219,205 \\
\hline $\begin{array}{l}\text { Gross Domestic } \\
\text { Product Per Capita } \\
2005 \text { in US } \$^{* *}\end{array}$ & $\begin{array}{r}239 \\
2,150,231\end{array}$ & $\begin{array}{r}368 \\
3,315,688 \\
R p\end{array}$ & $\begin{array}{r}360 \\
3,235,699\end{array}$ & $\begin{array}{r}1320 \\
11,876,000\end{array}$ \\
\hline Surface area in $\mathrm{km}^{2}$ & 4,051 & 7,000 & 49,880 & $1,919,317$ \\
\hline $\begin{array}{l}\text { Human Development } \\
\text { Index ranking in (scale } \\
1 \text { (best)-341(worst)) in } \\
2002\end{array}$ & 339 & 329 & $\begin{array}{r}\text { Lowest of all } \\
\text { Indonesia's } \\
\text { provinces in } \\
2002 \text { (ranking } \\
30)\end{array}$ & $\begin{array}{r}\text { Ranking } 108 \\
\text { out of } 177 \\
\text { countries } \\
\text { world-wide }\end{array}$ \\
\hline $\begin{array}{l}\text { Human Poverty Index } \\
\text { ranking in } 2002 \\
\text { (scale } 1 \text { (best)- } \\
341 \text { (worst) for districts) }\end{array}$ & 329 & 209 & $\begin{array}{r}\text { Ranking } 24 \\
\text { out of } 30 \text { prov- } \\
\text { inces in total }\end{array}$ & $\begin{array}{r}\text { Ranking } 41 \\
\text { among } 102 \\
\text { developing } \\
\text { countries for } \\
\text { which the } \\
\text { index has been } \\
\text { calculated }\end{array}$ \\
\hline $\begin{array}{l}\text { Percentage working } \\
\text { population with agri- } \\
\text { culture as main eco- } \\
\text { nomic activity in } 2002\end{array}$ & 87 & 84 & $(\text { in 2005) })^{* * *}$ & $(\text { in } 2005)^{* * * *}$ \\
\hline
\end{tabular}

* Source: BPS Statistics Indonesia at http://www.bps.go.id/ and http://ntt.bps. go.id, UNDP Human Development Report as published on http://hdr.undp.org/ statistics/data/countries.cfm?c=IDN, http://origin-hdr.undp.org/reports/detail_ reports.cfm?view=803 page 102, and World fact book of the CIA on http://www.cia. gov/cia/publications/factbook/.

* For comparative purposes the income figures are given in US \$, using an exchange rate of 1 US $\$=9.000$ Rupiah the convert the BPS income data.

*** http://ntt.bps.go.id/mploy/mp02.htm (accessed 13-8-2007)

**** http://www.bps.go.id/sector/employ/table2.shtml (accessed 13-8-2007)

backward and isolated area (Corner 1989:197). Economic indicators, like the Gross Regional Domestic Product per capita, which are used to make this inter-regional comparison, show a very low value for NTT.

These official statistics show that per capita income in 2005 in West Sumba was only 18 per cent and in East Sumba 28 per cent of the national average. It 
is hard to find data about income distribution, but in 1993 Ann Booth wrote that in NTT only 5 per cent of the population had a monthly expenditure that exceeded the national poverty line whereas in Java and Bali this is about 25 per cent (Booth 1993:53-83). In December 2005, Kompas newspaper reported that 59 per cent of the households in NTT were statistically registered as 'poor' (keluarga miskin). ${ }^{3}$ Yet, the macro economic indicators include only what is measured in terms of money, and many household requirements in the rural area of Sumba used to be met, and to some extent can still be met, without using cash, either through direct production, or through exchange of goods. Traditionally, wealth and poverty are measured in terms of houses, land, graves, livestock, food, and social relations (Vel 1994b:150-7).

There is no attempt to extract natural resources such as oil and gas and only little mining on Sumba, and the climate and soil are not very well suited for large-scale cash crop farms. This implies that, at least up to 2006, there are very few initiatives for investment on this island from outside. The local newspapers often report on new initiatives for industrial investments or estates, but West Sumba's district statistics on industries in 2002 show nearly blank tables. ${ }^{4}$

\section{Population}

In 2005 the total population of Sumba was 610,000, two-thirds of which live in West Sumba. An outsider perceives the population as 'Sumbanese', and whenever people from Sumba travel to other islands in Indonesia they present themselves as Sumbanese. On Sumba, however, there are many distinctions within the category of 'Sumbanese'. People who originally migrated from other islands - even if it was generations ago - are not regarded as Sumbanese. The largest group among these is the Savunese, from the neighbouring island Savu, who mostly live in East Sumba and make up 12 per cent of the population in that district.

The distinctions within the category 'Sumbanese' follow the division of traditional domains (elaborated on in Chapter III). These domains are vague geographical areas, 16 in West Sumba and 8 in East Sumba (Goh 1991:xii). They were autonomous 'kingdoms' in the pre-colonial era. At present, the quick answer to the question 'where do you come from' refers to these domains: orang Loli, orang Anakalang etcetera. There is a historical rivalry among

3 http://www.kompas.com/kompas-cetak/0512/16/daerah/2293247.htm(accessed 14-8-2007).

4 Badan Pusat Statistik Sumba Barat (2004), Sumba Barat dalam angka, Waikabubak: BPS, pp. 193-202. 


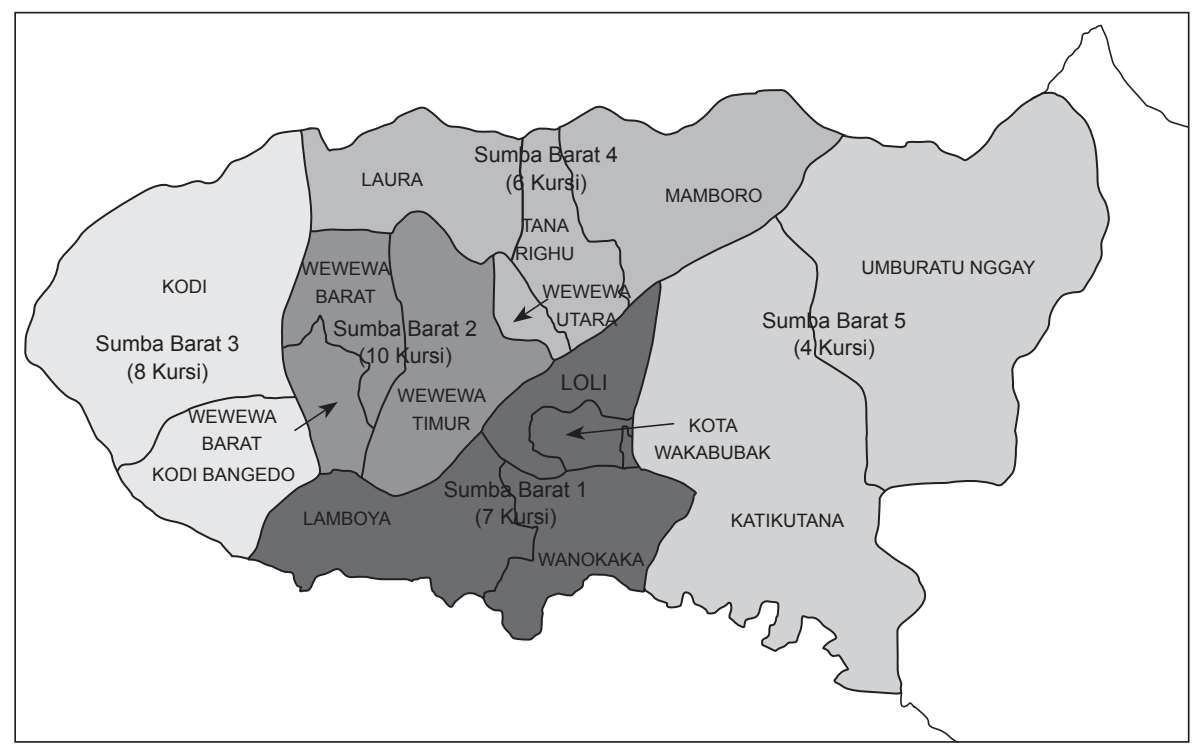

Map 2.3 Election areas for the 2004 General Elections in West Sumba. Source: Komisi Pemilihan Umum : http://www.kpu.go.id/peta/ peta_dprd_kota2.php?propinsi=Nusa\%20Tenggara\%20Timur\& prop_id=18\&peta=Daerah (accessed on 26-6-2006).

the various groups who identify with these domains because once they fought each other in internal wars and headhunting raids. The stories about the heroic acts of the past and the triumphs in warfare strengthen the politics of identity on Sumba. Chapter VI describes how the politics of identity inflamed the ethnic emotions of two opposing groups in 1998, which led to large-scale violence in Waikabubak. Chapter VIII presents a case of identity politics used to create new borders and unify the population within those borders. Chapter IX reveals how district head candidates try to use the internal ethnic distinctions as opportunistically as possible in their election campaigns. Such cases demonstrate how traditional domains remain politically relevant on Sumba; for example, the administrative division in sub-districts (kecamatan) follows roughly the borders of the traditional domains, and the election areas, created for the general elections in 2004, also resemble the traditional domains.

Installing democracy on Sumba introduced the direct election of District Heads. For the first time in history it was important how many people made up the constituency of each candidate. Although constituencies were based on other criteria as well, all candidates relied heavily on their ethnic back- 
ground to garner votes. Therefore, in the present democratic regime, the division in election areas is one of the most effective ways of discerning a historical background related to current population data on West Sumba, and in turn to understanding its district politics. Map 2.3 shows these areas with the number of seats in the district parliament that each area is allocated. This division is based on the number of voters in each area. Many leaders in the past came from election area five, covering the area where I did most field work, but now they are allocated only four parliament members out of the total of 35 .

The urban area, the capital town Waikabubak, is the only multi-ethnic community in West Sumba. It used to be part of the domain Loli, but as it became the administrative and economic centre of the district, many people from other areas migrated there.

\section{History of state formation on Sumba}

State and Christianity are closely linked on Sumba. The Dutch colonial government brought a centralized state to Sumba, and European missionaries were the ones to introduce and spread the Christian religion. Education and health care are usually regarded as state services, yet on Sumba these services were part of missionaries work. How did the introduction and spread of Christianity and the incorporation into the national State affect local leadership on Sumba? In this section state formation is discussed first in general terms, then in terms of the colonial background of contemporary leaders in Central Sumba. The subsequent section tells the history of the introduction of Christianity, which provides a basis for legal pluralism and the creation of Christian elite, and thus a Christian Sumbanese state.

Sumba has a relatively short colonial history. Commercial interest in Sumba was minimal. During the era of the Dutch East Indies Company (VOC) there were reports of trading opportunities on Sumba, especially for commerce in (sandal) wood, slaves and cotton, but the general lack of security on the island convinced traders not to establish permanent exchange activities there. The main interests of the Dutch Indies government in the eighteenth century were to keep the island out of the hands of other colonial powers (Wielenga 1949:9). After reports reached Batavia that a British ship was wrecked and raided off the coast of Sumba in 1838, the central Dutch Indies government ordered Resident Van den Dungen Grovinius in Kupang to go to Sumba in order to investigate how the island could be made safe and governable (Kapita 1976b:25). Subsequently he delegated this task to one of his staff members, Sjarif Abdoelrachman bin Aboebakar Alqadri, a relative of the sultan of Pontianak, who carried out the investigations and settled on 
Sumba in 1843 (De Roo van Alderwerelt 1906:247). He started profitable horse trade and became a very influential person. To the Sumbanese he represented the Dutch Indies government as he carried out his investigatory initiative and levied taxes on every horse exported (De Roo van Alderwerelt 1906:256-7). His settlement at the north coast of Sumba later grew to become the capital of the island, Waingapu.

In 1866, the first government official was instated on Sumba, Kontroleur S. Roos. He had four different tasks: 1 . to receive reimbursements for the load of raided shipwrecks, paid in horses; 2 . to study the situation and habits of the people on Sumba (in order to find out which method of indirect government rule would be legitimate, in other words compatible with Sumbanese adat); 3. to prevent slave trading; and, unofficially, 4. to keep an eye on the activities of Sjarif Abdoelrachman (Kapita 1976b:28). The latter person's influence had become a problem, since he encouraged internal warfare due to his profitable involvement in slave trade. According to De Roo van Alderwerelt, who was civiel gezaghebber which is the highest colonial government position on Sumba from 1885 until 1888 (Van den End 1987:684), the kontroleur was supposed to be a political agent of the Dutch Indies government, not the ruler of Sumba, and he was to act as advisor to the Sumbanese raja while leaving them to govern their own areas. This advising role was always firmly bolstered by the colonial government's ability to use force.

To understand the relationship between the colonial government and the Sumbanese leaders, we must take into account different perspectives. From the perspective of the colonial government, the contract which some raja of Sumba as signed in 1845 limited the sovereignty of the Sumbanese especially with regard to trade and alliances with foreigners other than the Dutch (De Roo van Alderwerelt 1906:299-316). De Roo's comments suggest that the Sumbanese raja just signed the contract as a ritual without understanding its content (De Roo van Alderwerelt 1906:276), and that the rajas did not have the authority, according their own customary law, to sign such contracts (De Roo van Alderwerelt 1906:272).

In 1877, Sjarif Abdoelrachman went to Kupang to account for his activities related to warfare on Sumba and involvement in slave trade (Kapita 1976b:38). A few months later he died in Kupang, ending a 34-year period in which he had been the broker between the colonial government and local leaders on Sumba. His activities had created involvement of colonial government in internal warfare to such an extent that Waingapu had become a hostile settlement for various ethnic groups on Sumba. When, in 1901, the rumour was spread that Waingapu would be captured by the raja of Lewa-Kambera, the Dutch colonial government decided to defend its inhabitants. The former policy of non-interference with internal affairs was put on hold and the Dutch Indies Government's authority was established through a violent campaign 
of 'pacification' of the island, which was completed in 1912.

The pacification included four major policy measures: (1) the release of slaves and prohibition of slave trade, (2) prohibition of internal warfare, and the declaration that all guns and arms must be handed over to the government, which in turn instituted its own monopoly of violence, (3) abeyance by the people of other government orders, such as to assist in road construction, and (4) compliance with taxes levied by the government. Local government officials were appointed, and in fact, the same system of indirect government rule remained in place, with the only difference being that the rajas now were subordinate to the central colonial government. The raja had lost warfare as a means to demonstrate and consolidate power, but taxation was a new source of suppression used to benefit the raja and his family. Traditionally, leaders on Sumba were only leaders within their own domain (Couvreur 1917:217). This changed with colonial rule. The colonial government appointed some of the maramba as raja or assistant raja, placing them into a larger structure and creating a new hierarchy.

While the Dutch colonial government was increasing its influence on Sumba, Protestant Christian missions began their activities on this island. The first Christians on Sumba were immigrants from the island Savu. At the request of two Sumbanese raja, four hundred Savunese were transferred by the colonial government from Savu to Sumba in 1860. Their migration was part of the Sumbanese raja's warfare strategies, which necessitated more people to protect their territory from the Endenese who raided Sumba and exported their captives as slaves (De Roo van Alderwerelt 1906:263-4). When in the 1860s Christianity became rooted on Savu, the Savunese on Sumba also started Christian congregations (Fox 1977:170). The first Dutch missionary Van Alphen arrived on Sumba in September 1881. In the first two decades of Dutch Protestant Christian missionary activity, the missionaries worked mostly with the Savunese in eastern Sumba, and their contact with Sumbanese population was limited to visits to the raja and supplying medical services to the missionary post's neighbours (Van den End 1987:5-6)

'Pacification' made Sumba more accessible for the missionaries. Their schools were the first on Sumba and through the education in both schools and church they created a new intellectual elite. The educated Sumbanese became the local government officials. The traditional elite's children were the first to become educated. So after losing warfare as a means of establishing authority, the local rulers not only had taxation as a new means of power but they also had access to the governing institutions through their educated children, who gradually were appointed to leadership offices. The missions ran schools on Sumba and they also provided scholarships for Sumbanese students to attend universities in other parts of Indonesia, in Kupang, Ujung Pandang (Makassar) and Salatiga. Janet Hoskins described how raja Horo, 
the father of a candidate for deputy district Head in the 2005 elections discussed in chapter IX, was made into a local ruler by joint efforts of the missions and colonial government:

In the 1920s he [Rangga Horo,] became the only student from Kodi to attend a small theological seminary in Karuni that would train village evangelists (guru injil). [...] [The Dutch] found in Rangga Horo, now baptized 'Hermanus', their most diligent student. Of all the native administrators he was the only one capable of writing reports in the appropriate style, and the one most skilled in record keeping. He adopted Western dress, and after independence in 1950 decided that one of the best ways to 'modernize' Kodi was to require that men should cut their hair and women wear blouses or kabayas at all public occasions. His enthusiastic embrace of all the trappings of Dutch beschaving ('civilization') provoked criticism from some quarters in his own society, but allowed him to rise to the very top of the island administration during the colonial period. (Hoskins 1998:93.)

After the declaration of independence of the Republic of Indonesia, changes

Figure 2.1 Government administrative structure since 1979, with Heads of government and examples of administrative units from West Sumba

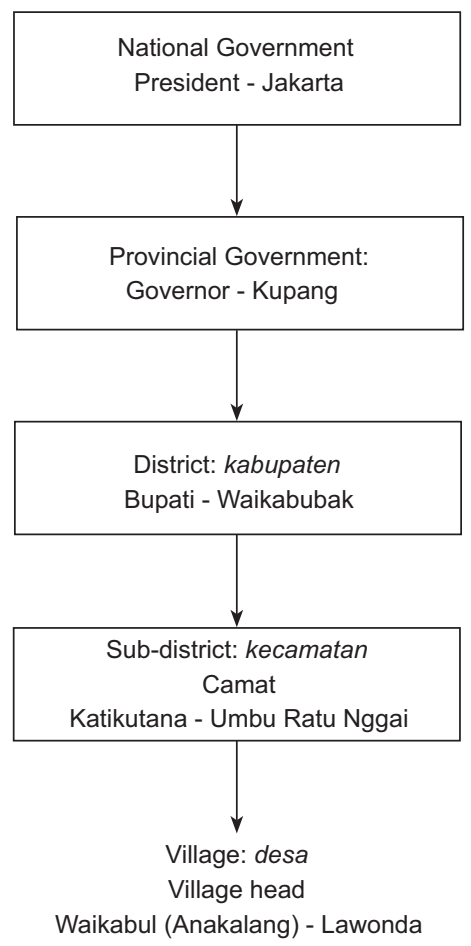


in the running of the government on Sumba were not as dramatic as national changes. In fact, the same way of indirect rule remained in place, with the difference that the local rules were now subordinate to the national Indonesian government. The missions still maintained a leading role in education, social services, and health care. With Suharto's New Order, after 1965, Sumba experienced for the first time in its history the rule of the bureaucracy as it was organized and instructed from the national centre, Jakarta. The New Order government invested large amounts of money in schools so that every child would be able to attend basic education in a sekolah inpres (public primary school) and also in roads, healthcare, electricity, etc. In financial terms the flow of money from 'Java' to Sumba was much larger than the return flow. Suharto's administration also had influence on the religious developments in Sumba, as anyone who tried to take an exam or to become appointed in government service was required to be a registered member of one of the five officially recognized religions. The traditional Sumbanese religion is not included in the five and therefore the easiest solution on Sumba was to register as member of the Protestant Christian Church. Compelled by this political pressure more than half of the population of Sumba is officially Protestant Christian.

The specific relationship between the state and social groups on Sumba ('society') is crucial in understanding local politics. 'The state' is more complicated than a monolith governing the nation from the centre. Migdal (1994:16) argued that in order to understand states and political change, one should disaggregate the state, paying special attention to its parts far from what is usually considered the pinnacle of power. A second claim in this theory is that states and other social forces may be mutually empowering. Disaggregating the state from a regional perspective in Indonesia first of all means following the hierarchy from the top, the president, down to the very lowest governing offices at village level. The second way of disaggregating is to distinguish the various types of institutions or offices that can be included in 'the state' in Indonesia. The state comprises the governing officials, but also includes the army, police and-during the New Order period, Golkar (Smith Kipp 1993:87). In the local context, as for example in Waikabubak, the state presents itself especially through these local officials. They are the brokers between central policies and local interests. They are also involved in local society, and their identity comes from sources that are relevant on Sumba.

In the political history of Sumba, the members of the local Sumbanese elite have always tried to use the state for furthering their own interests. Since there has never been a local ruler of Sumba who has been accepted by every group, there has always been a struggle between social groups and their leaders on Sumba for access to the resources of the state. First the fights were for who got military support by the colonial government for internal warfare, then there was struggle for the positions that gave the right to levy taxes. The 
broadest and most recent competition is about who gets access to government offices, opening the way to influence and steady sources of income.

\section{State and Sumbanese Christianity}

Christian missions supported the colonial rule by educating local elite to be colonial administrators. In addition to this direct link, Christianization influenced many other aspects of Sumbanese society. It was the introduction of a universalizing religion that enabled Sumbanese to imagine themselves as part of larger totalities, and not see themselves as just Sumbanese. It also brought alternative ideas and ways of seeing things to the island's population.

Before there were contacts with people from other areas, Sumbanese worshipped their ancestors and practiced their traditional marapu ${ }^{5}$ beliefs. This belief system provided guidelines for social behaviour, explained the features of nature and every-day life, and provided a sense of belonging for every individual by linking him or her to venerated ancestors in the spiritual world (Wielenga 1949:71-7). The past defined the position of those living in the present. The past itself was regarded, in the words of Janet Hoskins, as heritage, that is 'an array of established sequences, like the stages of a ritual, which can be instantiated in various forms' (Hoskins 1993:308).

Catholicism was introduced in Southeast Asia in the sixteenth century; Protestant Christian missionaries entered the area only in the nineteenth century in association with the high colonial period (Keyes 1996:280).

Protestant missionaries who came from Europe and America to Southeast Asia in the early nineteenth century were impelled by a strong belief that they had a moral obligation to bring the truth of the Gospel to those who had not yet heard it. Many became missionaries because of a conversion experience they had themselves gone through. Even without the conversion experience, the act of becoming a missionary, which at the time entailed leaving home perhaps forever, working among people of wholly alien cultures, and undergoing hardships of physical discomfort and disease, gave most missionaries a charismatic aura. They would draw on their charismatic qualities to invest their religious work with immediate authority. As legatees of the Reformation, however, Protestant missionaries saw their authority as rooted ultimately not in their personal charisma but in the sacred texts. They believed that through study of the Bible, or more precisely, the translated Bible, they had gained a

5 Marapu is defined by Louis Onvlee as 'mythical ancestors of a genealogical group (kabihu, clan) who belong to those who according oral accounts arrived on Sumba first' (Onvlee 1984: 279); D.K. Wielenga extends this definition to 'all who exert power in the invisible world' and this invisible world is where the spirits of the deceased forefathers reside (Wielenga 1949:71). 
rational understanding of God's way that would prove superior to the teachings of any other religion (Keyes 1996:282).

Missionaries settled on Sumba only by the end of the nineteenth century, and presented the natives with their first confrontation with a totally different type of belief. European missionaries found that 'both a cosmology and a theodicy seemed to be absent' because they could not recognize similarities between such concepts and the elaborate narratives of Sumbanese about voyages of the ancestors or the history of a particular sacred object. When asked about issues that were familiar themes in Western religious discourse, such as the ultimate destination of the soul, the origin of the human race, and the underlying reasons for suffering (beyond case-by-case instances of a given spirit's anger), most Kodi simply confessed that they did not know (Hoskins 1993:280). During marapu rituals the ratu (traditional Sumbanese priests) would narrate in ritual speech stories about the past and the ancestors.

A particular partisan version of the past was passed down a descent line or transmitted along with certain valuables, but no more all-encompassing questions were asked. [...] Explanations were undertaken piecemeal in terms of the context at hand, instead of being formulated in the abstract language of religious doctrine or dogma. A primary concern was for ritual correctness rather than cosmological speculation. (Hoskins 1993:280.)

Hoskins (1993), Keane (2007) and Kuipers (1998), have studied the politics of narratives in the local context. Their argument is that the cosmological myths and traditional narratives are used as a 'language of argument rather than a chorus of agreement' (Hoskins 1993:88). Those who can tell the narrative in the most correct and fluent way will be able to convey to the audience that their link to the most powerful marapu is strong. Consequently they gain the authority to dominate in the present and visible world. This style of ritual speech is used by Sumbanese politicians, maintaining the tradition that the form of speech expresses the extent of authority.

When Christianity ${ }^{6}$ came to Sumba, its first confrontation with traditional religion was over differences in ritual practices. Going to church on a fixed moment in time - without any particular reason in the local context and doing this every seventh day, was a main characteristic of the new religion and introduced the concept of the 'week' on Sumba.

Christian missionaries also introduced school education. In the last decade

6 With the term 'Christianity' I refer to the world religion in general, brought to Sumba by European missionaries, including both the Protestant Christian Church and the Catholic Church. Only when the context on Sumba requires more specificity do I use terms 'Protestant', 'Catholic' or the names of the churches. 


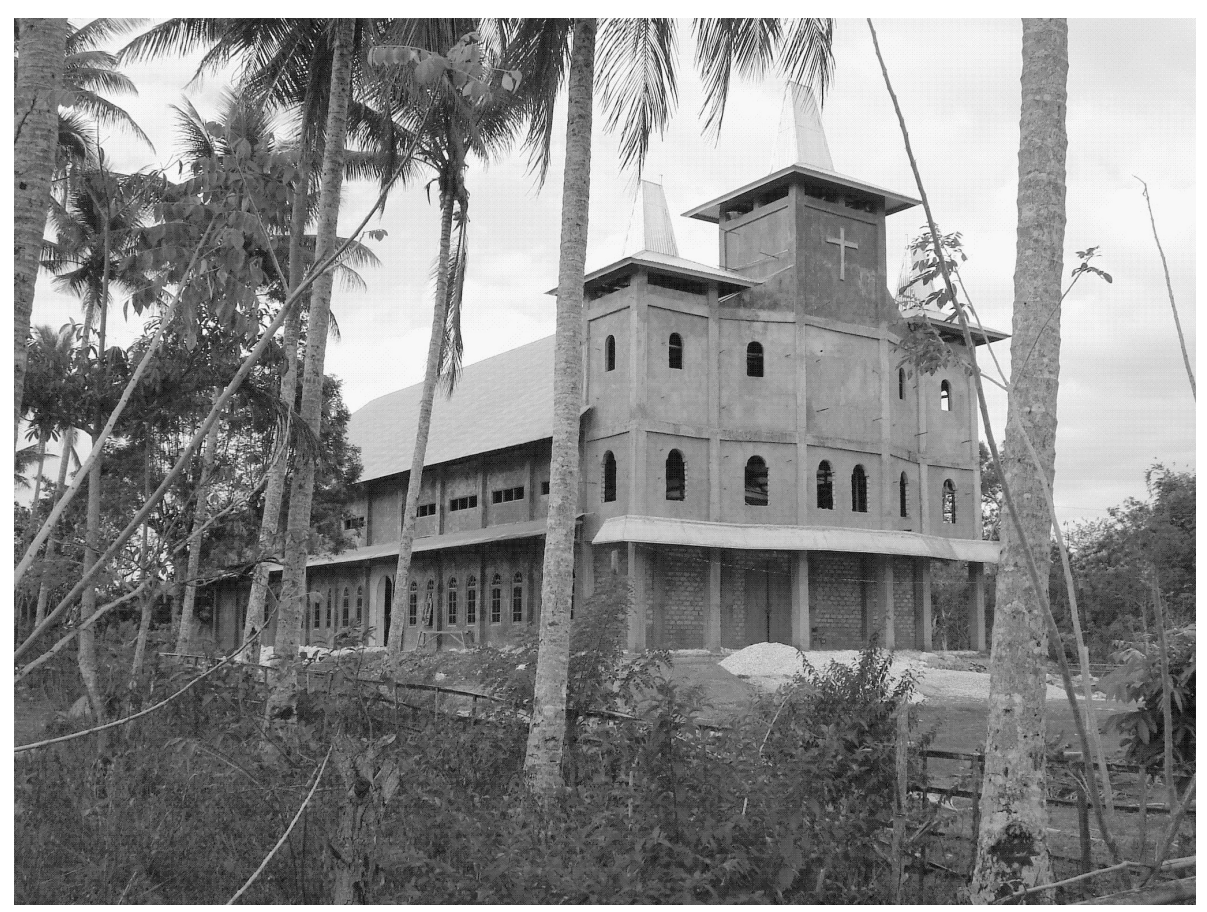

The new Christian church in Anakalang, September 2006

of the nineteenth century the Jesuit mission in north-west Sumba started a school. After ten years it was closed again due to lack of success: the pupils all went home and were not converted to Catholicism. In 1907 Reverend Wielenga reopened the school in Karuni. It was consistent with Dutch colonial policy at that time to train future colonial administrators, and admission was confined to boys and girls who claimed to be of noble rank (Hoskins 1993:282). With the 'Flores-Sumba Contract' of 1913 the colonial government tried to prevent further competition between Catholic and Protestant missionaries, and delegating Flores to the Catholics and Sumba to the Protestants. The Protestant school on Sumba received government subsidies and official approval. From this time onwards the traditional Sumbanese elites' children were educated in Christian schools. The connection of Christianity with schools also led to literacy being regarded as an attribute of Christianity. Some of the elementary school's pupils were selected to pursue further studies, and enter boarding school at the house of the missionary. There they were expected to convert to Christianity. Hoskins wrote that 'two things marked the new Christian community: the respect accorded to the written word, which was treated as 
sacred, and the requirement to attend church service on Sundays' (Hoskins 1993:284). She also stated that in the late colonial period Kodinese made a distinction between their own social and geographic sphere of the ancestral village where they worshipped their spirits, whereas everything beyond the island and those things pertaining to government offices, hospitals and schools belonged to the realm of the foreigners and the Christian religion (Hoskins 1993:287). Christianity was seen as an entrance to the wider world.

European missionaries did not only bring a new religion, but along came many elements of Western European culture. The Protestant and the Catholic Churches were the churches of foreigners, whose dogma and liturgy were so fixed that, although in theory the Protestant Church was open to local cultural influences, there were no adjusted forms of ritual in the Christian services before 1940 (Van den End 1988:181). As of 2005, being Christian is part of Sumbanese identity for many of the island's inhabitants. What turned this foreign religion into something Sumbanese? I argue that due to growing membership in the Christian Church, the character and content of the services and the type of ceremonies held outside the Church building have gradually changed from the prescribed forms set by European missionaries, to a Sumbanese version of Christianity that includes new type of rituals which emphasize those parts of Christianity that appeal to traditional Sumbanese religious feelings and abolished the rules and practices that were perceived too foreign.

Lorraine Aragon describes a similar process in Sulawesi in her book Fields of the Lord, about how the Tobako in Central Sulawesi created their own version of Protestantism. 'Central Sulawesi highlanders have transposed and relabelled their pre-Christian deities to confirm the missionary-supplied categories such as God, Jesus, the Holy Spirit, and Satan' (Aragon 2000:32). They regard themselves as true and fanatic Christians. Aragon's major argument is that this world religion could be modified to fit local conditions and local philosophy to form Central Sulawesi Protestantism, which is not just a Christian-coated style of animism.

Tobako Protestantism is an indigenized Christianity built upon almost a century of conversation with national and international representatives of foreign religious orthodoxies. Central Sulawesi Protestantism rests upon a differing set of ecological and historical conditions that are interpreted through an oral society's firm faith in a unified cosmos. (Aragon 2000:36.)

Aragon makes these points about the indigenization of Christianity in such a way to suggest that this is a natural process that happens everywhere in the world, namely, that people adjust new ideas to their existing local philosophy. The question why people like the Tobako did not stick to their own traditional religion remains. Aragon offers the role of state intervention as an 
explanation. At first Christianity was instrumental for colonialism; by converting the natives, the missionaries created bridges of inter-ethnical relationships and support for colonial rule. After independence in 1945 Indonesian nationalism was formulated in terms of modernity and economic development. Modernity was strongly associated with Christianity. During the New Order of Suharto, the pressure to convert to one of the officially recognized religions became even stronger. After 1965 being 'without religion' could be equated with communist sympathy, a label that at least would end all career perspectives.

On Sumba the history of conversion to Christianity is rather comparable to that of Central Sulawesi. In both regions various ethnic minorities were converted, and major efforts of the missionaries were in the field of education and development. One of the differences between Sulawesi and Sumba, however, is that in Sumba there is no Muslim majority, a fact which would assign a distinctive identity for minorities. Protestant Christian identity does not make sense in Sumba as a strategy to distinguish oneself from the inhabitants of the neighbouring territory. Christianity is a uniting characteristic of modern, educated Sumbanese, who are well connected to the Indonesian state. As such, it can be used as a political identity, as done in the election campaigns described in chapter IX.

The fact that many people have become Protestant Christians has changed the character of the Christian Church on Sumba from a small foreign religious community to the church of the majority of the Sumbanese. By the 1980s the Protestant Christian Church had become the church of the majority on Sumba. Van Halsema (1995:83) reports that by 1976 the GKS had 52,000 members and that this number had grown to 100,000 in 1986. After 1986, when I lived in West Sumba, there were mass baptism services, where for example in Maradesa, part of congregation Lawonda, over 2300 people were baptised in one service. This spectacular increase in the eighties was due to political pressure. Any person who had something to do with the bureaucracy, such as school children who wanted to take their exams or graduates who wanted to apply for a job, would be better off after registering as Christian. In the West Sumba regional parliament Golkar seats were divided at that time between the Protestant and Catholic politicians according to the numbers of registered adherence to their respective churches. This stimulated large baptism campaigns from Waikabubak into the mountains of the interior of West Sumba.

A congregation that sees its membership increase tenfold has a significant challenge in attending to the needs and education of the new members. In the congregation Lawonda, of which we were members during our stay in Sumba, there was a severe lack of trained church cadre in the late eighties. People who were leaders in other spheres of village life, such as, adat elders or neighbourhood government members, were elected as members of the Church 
council and had to teach and guide the (other) new members. Therefore this period strongly stimulated the creation of Sumbanese Protestantism. By 1987 there were 53 ministers on Sumba, all indigenous Sumbanese. Some of these may have been consciously looking for locally relevant and socially accepted content of Protestantism. In a chapter on theological education on Sumba Andreas Yewangoe (1995:123) gives an example of issues posed by young Sumbanese Christian theology students, such as 'how to compare the Biblical concept of ' $\mathrm{sin}^{\prime}$ with the Sumbanese concept njala. ${ }^{7}$ This is exactly the same type of question posed by the Europeans when they were confronted with the problem how to translate their message. Hoskins (1993:303) also reports discussions in Kodi in the eighties among Protestant ministers:

Although some Church leaders insist on a narrower interpretation on the content of 'religion', many followers clearly wish to accept Christianity along with traditional practices. They want someone to develop an argument for syncretism that makes sense to its real judges - the ambivalent and divided villagers of the region, who do not want to abandon their ancestors yet still seek to move into a newer and wider world.

All these discussions took place under the repressive New Order regime that promoted adherence to one of the five religions the regime recognized. After the demise of the New Order Indonesians were free again to decide on their religious adherence, however recent statistics in West Sumba do not show a decline in the numbers of Christians. In contrast, its membership is increasing. The increase in adherents of the Protestant Christian Church is partly due to growing popularity of evangelical churches, which are relatively new to Sumba. Their services are appealing not only because of greater emphasis on ritual and enthusiasm, but also due to such strategies as distribution of free rice and clothes. ${ }^{8}$ Apparently, there has not been much change since Keane's observation in the 1980s that converts in Anakalang do not develop narratives of new insights or transformed lives. 'They typically portray entering the church as an act appropriate for educated persons, as an acknowledgement of the power of the government, the modern epoch, or one's kin, or as a more rational, economic mode of life in which one eschews the expense of sacrifices' (Keane 2007:164).

The number of Muslims, Buddhist and Hindu on Sumba is very small, and usually most of them are immigrants from other parts of Indonesia. In coastal areas of Sumba there are some Muslim communities, including Sumbanese who have become Muslims, usually because of intermarriage with Muslims

$7 \quad$ Njala means: 'mistake, wrong, missed' (Onvlee 1984:369).

8 Interview with U. Dingu, secretary general of the GKS, February 2004. 
Table 2.2 Religious adherence in West Sumba according to government statistics of 2000 and 2002, in number of adherents

\begin{tabular}{|c|c|c|c|c|c|c|c|}
\hline Religion & Islam & $\begin{array}{l}\text { Protestant } \\
\text { Christian }\end{array}$ & Catholic & Hindu & Buddhist & $\begin{array}{l}\text { Other, } \\
\text { mostly } \\
\text { Marapu }\end{array}$ & $\begin{array}{l}\text { Total } \\
\text { popula- } \\
\text { tion }\end{array}$ \\
\hline $\begin{array}{l}\text { Number of } \\
\text { adherents } \\
\text { In } 2000\end{array}$ & 8,161 & 154,425 & 90,986 & 327 & 5 & 96,802 & 350,706 \\
\hline In 2002 & 11,224 & 197,888 & 105,385 & 327 & 5 & 69,157 & \\
\hline $\begin{array}{l}\text { As percent- } \\
\text { age of total } \\
\text { population in } \\
2000\end{array}$ & 2 & 44 & 26 & 0 & 0 & 28 & 100 \\
\hline In 2002 & 3 & 52 & 27 & 0 & 0 & 18 & 100 \\
\hline
\end{tabular}

Source: Sumba Barat in Figures 2000 and 2002, Badan Pusat Statistik, Kabupaten Sumba Barat, Province NTT.

from other islands. Among the central government civil servants, who mostly live in Waikabubak, there are many Muslims.

State as career: Umbu Djima and the forms of capital

The overview of historical developments and statistics is one way of finding out about the state in Sumba. It is an outsider's view that organizes events into relevant categories. On Sumba, conversely, the past is conveyed through narratives in which certain people and objects figure prominently. In this section I present a life history of a retired ex-bupati, as an alternative way to describe the historical developments of state formation and introduction of Christianity in Sumba, their interaction, and how they are experienced and affect people's lives. I asked Umbu Djima to tell me about his life, when I visited him and his wife at home informally. Although this question is simple, a life history is not an objective story that is just there to be collected. Janet Hoskins warns that 'through 'telling their lives' people do not only provide information about themselves but also fashion their identities in a particular way, constructing a 'self' for public consumption' (Hoskins 1998:1). Umbu Djima has known me for many years and since 1986, when I was development worker in one of the rural areas of 'his' kabupaten. Since 1998 I have come to Anakalang many times and stayed with his female cousin who lives next door, and since our introduction in 1984, he has become a friend and source of information. Every time I stayed there I visited Umbu Djima, walking to his 
house through the garden that connects my friend's home to his house. At the day of the interview we had been discussing the 2004 parliament elections, the new parties and in particular the characteristics of the local elections' candidates. After dinner, Umbu Djima liked to talk about his life, listing his accomplishments and offices and explaining the choices, considerations and experiences of successive periods in his life. As I have often heard often other prominent Sumbanese men say about their lives, he stressed that it was not strategy, luck or fate that brought him where he was, but the hand of God. I have translated and summarized Umbu Djima's words into the biography below. It details how a boy from noble descent in Anakalang gradually moved upwards to positions from which the state's resources could be controlled. The latter process requires a great skill of accumulating and transforming various types of capital. Umbu Djima's life history is a long narrative full of examples on how he succeeded to make such acquisitions. Different types of capital are accumulated and converted from one type into the other. In his article 'The forms of capital' Bourdieu states that:

capital can present itself in three fundamental guises: economic capital, which is immediately and directly convertible into money and may be institutionalized in the form of property rights; as cultural capital, which is convertible, on certain conditions, into economic capital and may be institutionalized in the form of educational qualifications; and as social capital, made up of social obligations ('connections'), which is convertible, in certain conditions, into economic capital and may be institutionalized in the form of a title of nobility (Bourdieu 1986:243).

These distinctions are helpful in understanding how the state is embedded in society in Sumba. It also clarifies why some Sumbanese are more successful than others, and why activities that at first glance seem to be 'just cultural' manifestations are so important for politics on Sumba. The use of 'capital' is a way of addressing differential resources of power, and of linking an analysis of the cultural to that of the economic. The key theoretical question is how these different types of capital transform themselves into each other in order to maximize accumulation. ${ }^{9}$

Umbu Djima was born in 1939 in Central Sumba, in Anakalang, a son of one of the noble families of this area. His female cousin told me that, according to the local myth of origin, there had always been a rivalry between the founding fathers of Anakalang's lineages. The authority to rule and decide on

$9 \quad$ Schuller, Baron and Field 2000:4. 'Social capital' is not used in the way similar to the World Bank following Putnam's approach to social capital, as applied to Indonesia by Bebbington, Dharmawan, Fahmi and Guggenheim (2006). Their approach is to apply the concept in an instrumental way to stimulate village institutions in order to achieve community driven development and foster social values that can countervail corruption by state officials. 
the division of land was the object of this rivalry, and it still exists, adapted to modern times, in 2006. From Kapita's book on Sumbanese history we know that in 1880, the Dutch Indies colonial government installed Umbu Dongu Ubini Mesa as the first raja of Anakalang and handed to him the golden stave, the symbol of colonial blessing of traditional leadership (Kapita 1976a:60). After the Second World War his grandson Umbu Remu Samapati was elected as the second bupati of West Sumba, and moved to the capital Waikabubak. His brother-in-law Umbu Sulung Ibilona, succeeded him as raja Anakalang and Umbu Djima was his eldest son.

Umbu Djima remembers his early youth in his home kampong as one of freedom and privilege. ${ }^{10} \mathrm{He}$ was the oldest of Umbu Sulung's children, the first child among seven children of the first wife. His father had officially four wives. When he lived with his parents in Anakalang he learned a lot about Sumbanese adat, since adat ceremonies and negotiations often took place in or near his home kampong. Umbu Djima was sent to the Christian school in Waibakul in 1946. When he graduated in 1952 he went to secondary school in the center of missionary activities, Payeti, in East Sumba. He followed the official curriculum successfully, and was initiated into Christian culture. Yet, in retrospect, he noted that being subject to missionaries' home rules and discipline was the most striking experience of those years. As son of the raja he was shocked when assigned household chores. After the second grade of school in Payeti he moved to Waikabubak in West Sumba, and graduated in 1958 from secondary school. He continued his education on Java, because at that time there was no higher school on Sumba. He was not sponsored by a church scholarship, because of a temporary crisis in the Protestant Christian Church of Sumba due to the political crisis between Indonesia and the Netherlands over Dutch New Guinea (Van den End 1987:584-7). He went to college and was sponsored by his own family who could afford to sell livestock to cover the expenses. He went to Salatiga in Central Java, one of the Christian centers on that island, where he lived with fellow Sumbanese students. Then he studied at the Universitas Gadjah Mada in Yogyakarta with the faculty of social and political sciences. He was an active member of the Gerakan Mahasiswa Kristen Indonesia (GMKI, Indonesian Student Christian Movement). When he finished the first part of this study in 1965 he was immediately employed by the government of NTT, as civil servant in the office of the governor.

Before taking up this position Umbu Djima returned to Sumba to get married. His wife was the daughter of a noble family from Loli in West Sumba. Together they went to Kupang in early 1966, where he worked at a new 
office for urusan pusat (central government policies) in NTT. At the governor's office, there were at that time only seven well-educated employees, all of whom had to teach at the local university. In 1968, Umbu Djima became head of the office and director of the Akademi Pemerintahan Dalam Negeri (Academy for Domestic Public Administration) in Kupang, where many civil servants received their education. Additionally, he was member of the province's parliament (DPRD-I) from 1968 to 1971.

In 1974, the next phase in his career began with his promotion to the Head of the Department of Education and Culture, and his election as dean of the Cendana University in Kupang. In 1975, he was selected by the Ministry of Domestic Affairs to participate in a one-year program for advancing civil servants in Nice, France. It was his first experience abroad. The classes centered on regional government, since the French system seemed to be similar to the Indonesia one. The way of life in Europe, the language, the habits, the silence and cold weather were the most lasting impressions for Umbu Djima, as was the discipline required for time management and a work ethic. Upon his return, he accepted a new position as assistant secretary of the governor, Ben Mboi, and after three years he moved to the Head of BP7,11 a new institution that was founded to increase the social diffusion and acceptance of the New Order's ideology. During this period Umbu Djima was also Golkar representative of the NTT province in the People's Consultative Assembly (Musyawarah Perwakilan Rakyat, MPR) in Jakarta, where he and his wife maintained a household. The Kupang residence continued to be a haven for Sumbanese students and relatives, who sometimes numbered up to 40 people. When the bupati of West Sumba died in 1984, Governor Ben Mboi asked Umbu Djima to be his successor. At that time it was Golkar and the Army who decided on the candidates, and in practice the governor who also had a military rank had the biggest say. Although Umbu Djima was not originally enthusiastic about this position, which at that time was perceived as a step down to a lower level of government, he agreed and was West Sumba's bupati from 1985 until 1995. Perhaps motivated by his prior experiences in foreign cultural contexts, his primary program was to introduce 'new ways', heka pata, which would put an end to what he called 'wasteful traditional ceremonies' and would rationalize production practices in agriculture. He was bupati in the tradition of his predecessors: a home grown political leader, the son or grandson of the colonial raja, who ruled as member of the New Order establishment. In West Sumba, unlike other parts of Indonesia, the strength of the New Order regime was not in its capacity for repression, but in the

11 Badan Pembinaan, Penyelenggaraan, Penegaraan, Pendidikan, Pedoman, Penghayatan dan Pengamalan Pancasila. 
record of successful development and maintenance of civil peace (Mitchell and Gunawan 2000a:2). During this period the only political organization available was Golkar, and therefore 'Golkar had the service of many able and idealistic men and women at its disposal and it had earned legitimacy in office from a long record of achievement' (Mitchell and Gunawan 2000a:2).

After Umbu Djima retired in 1995, he was elected in 1997 as a member of the National Parliament DPR-RI in Jakarta for Golkar. He was a member of this parliament during the demise of the Suharto regime and thus a first hand witness to Reformasi.

In 1999, he retired from this post and returned to his home in Waikabubak, Sumba and had built a new, large house in traditional style but with modern building materials and comfort in his home village Anakalang. In 2000, he started activities as the chairman for the local Church's building committee.

Umbu Djima's life history reveals that he is an expert in Indonesian politics, from Jakarta to Sumbanese village. It is also a testimony of his wealth in cultural and social capital. Bourdieu argues that the amount of cultural capital connected to a person can be measured from the length of its acquisition. In Umbu Djima's case, this included 20 years of formal education, supplemented with many years of additional learning as University lecturer and as a participant in the course in France for Indonesian civil servants. There are only few people of his generation on Sumba who have had a similar education and experience. His fields of expertise, for which he is respected in Sumba, include traditional Sumbanese culture, the culture and teachings of the Protestant Christian Church, the bureaucracy, Indonesian politics from the national to the village level, and knowledge of foreign cultures. The photographs of many prestigious occasions in his house, horse race trophies, and the large house in the village where he lives most of the time are the most obvious symbols of his capital. His titles doctorandus, (mantan (former)) bupati and most recently chairman of the Church building committee are evidence of his cultural institutional status.

A career like Umbu Djima's requires economic capital. He could study in Java because his family was able to afford it: they could sell livestock to get money to pay for school fees and boarding costs. Economic capital was transformed into cultural and social capital: those relatives who contributed livestock for paying school fees established a debt, which later could be rewarded, for example, when their children could stay at Umbu Djima's house in Kupang in order to have access to higher education. His offices as bureaucrat, lecturer, member of parliament and bupati all supplied him with economic capital.

Umbu Djima's life history contains two decisions which involved him more thoroughly in kinship network. First, he married a Sumbanese woman, 
according to the traditional rules of preferential marriage, re-establishing marriage alliance between his own and another important sub-ethnic group on Sumba, and opening the way to use this type of social capital for political purposes. Second, he ultimately returned to Sumba to continue his career as bupati and to be amongst fellow Sumbanese, where political success requires a good position in local networks. The material obligations within such networks can become a heavy burden. Other Sumbanese men of Umbu Djima's generation with similar biographies made different choices. When I listed the characteristics of 'successful' Sumbanese, I found that many Sumbanese with a successful career married women of different ethnic origin; that fact excluded them from many of the obligations of Sumbanese marriage affiliation, which could drain their wealth. Sumbanese who reside outside Sumba can live a more individualized life, which facilitates accumulation of economic capital.

During his long career Umbu Djima became part of many social networks, such as, the kinship network in his home village, the Christian network through the missionaries schools on Sumba, the Sumbanese students' network, the Indonesian Christian students' network, the network with the pupils from the Academy in Kupang where he taught for many years, bureaucratic networks, and last but not least Golkar. Accumulating capital social, economic and cultural is the way to obtain power, and it is the activity at the heart of Uma-politics. Every person's position in terms of power can be explained by assessing his or her assets in these different forms of capital. Social network connections can only be transformed into status or economic capital if they imply durable obligations subjectively felt or institutionally guaranteed. Bourdieu argues that,

this is done through the alchemy of consecration, the symbolic constitution produced by social institution as a relative, brother, cousin or as knight, heir, or donator and endlessly reproduced in and through the exchange (of gifts, words, women, etc.) which it encourages and which presupposed and produces mutual knowledge and recognition. Exchange transforms the things exchanged into signs of recognition and, through the mutual recognition and the recognition of group membership which it implies, re-produces the groups. By the same token, it reaffirms the limits of the group. (Bourdieu 1986:250.)

Chapter III will elaborate on the cultural repertoire in West Sumba which is an important source of cultural, symbolic and social capital. 
The state as bureaucratic procedures

Umbu Djima's life history makes clear that he is one of the elite, and a prominent member of the political class. Those who do not belong to that class cannot easily identify with the state. They experience its existence in other forms, most of all as bureaucratic procedures.

In Seeing like a state James Scott (1998) describes how states make populations 'visible' or 'legible' through permanent surnames, standardization of weights and measures, cadastral surveys, official languages and other ways of standardising citizenship and identifying populations generally and nationally, rather than specifically and locally. The Indonesian state categorizes the Sumbanese according to criteria of national policy relevance. The state bureaucracy does not keep records of issues that are important to traditional Sumbanese identity, such as clan and domain of origin. Personal distinctions, however, which do matter to the state, are found on the identity card, the kartu tanda penduduk (KTP). The identity card gives the owner a number and an official name, and it registers blood group, gender, date of birth, marital status, religion, profession, and address in terms of the state's administrative divisions. For Indonesian residents over 17 years of age it is compulsory to own one.

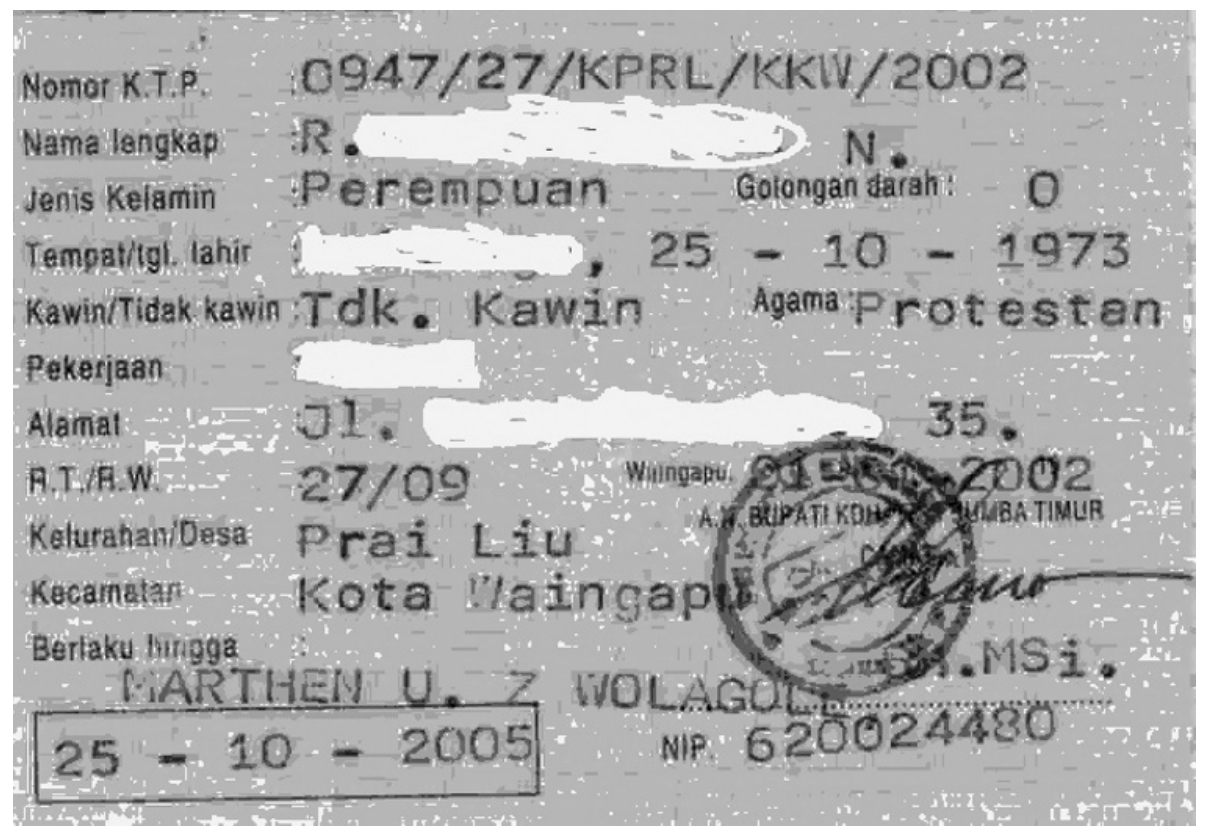

Figure 2.2. Identity card (KTP) 
People who live far out in the mountains in Sumba could still do without an identity card, living their lives in the village, making a living through agriculture and only occasionally paying a visit to relatives or the market elsewhere on Sumba. Yet any contact with the state requires an Indonesian identity. To get a card one has to enter the sphere of bureaucracy and have a passport photograph taken. It requires money and surrender to a different type of authority than the traditional one. To be able to get an identity card one has to submit a photocopy of the family document and the birth certificate. The function of the birth certificate particularly sheds light on the spheres of life to which the Indonesian identity is most relevant:.

Table 2.3. The Birth Certificate's function

For legal status

Entering school, from kindergarten to university

Applying for a job and applying for membership of Indonesian police and armed forces

Getting an ID card/ family document/ family registration number

Getting a driving license

Applying for a passport

Paying family allowances

Establishing a will

Applying for scholarship

Applying for insurance

Registration of marriage

Performing the pilgrimage

Obtaining a death certificate

Getting a divorce

Registering a new child

Adopting a child

Voting in elections

Source: http://www.jakarta.go.id/en/layanan/masyarakat/surat_ket_lahir.htm (accessed on 14-9-2004)

It is obvious that this registration is necessary for obtaining governmentissued documents. From the Sumbanese perspective, it is disputable whether the Indonesian State is the authority providing legal status, because on Sumba land rights and disputes are still more a matter for customary law than state law. The Sumbanese regard marriage, death, divorce, child recognition and adoption primarily as matters for adat, and would only register these events with the government if there was some very specific reason. Population statistics on Sumba are therefore not very reliable if they are only based on official registrations. 


\section{The state as economic sector}

The state appropriates part of its citizens' economic revenues and redistributes those funds. Regions are evaluated in the economic terms of how much they contribute to the national treasury and how much they receive in return. Sumba is part of the province of East Nusa Tenggara (Nusa Tenggara Timur, NTT), one of the poorest in Indonesia, where between 1996 and 2000 on only 0.65 per cent of the Indonesian national gross domestic product average was generated. ${ }^{12}$

The figures in Table 1 clearly show a very small per capita income, but the level of poverty of the Sumbanese population is a matter of debate among statisticians and policy makers (Betke and Ritonga 2004). The macro figures do not include income from barter, which is a major type of revenue in Sumba. Food especially is either a product of one's own cultivation or obtained through barter trade, and therefore invisible in the statistics (Vel 1994a:35-8). Despite this component of its economy, Sumba remains a very resource poor island. Cashew nuts, vanilla, candlenuts and cacao were the most promising crops for export to other regions. During 2004-2006 kutu lak (shellac) ${ }^{13}$ had become a major export commodity. Sandalwood, which used to be the island's major commodity, is now officially banned from trade. Informal sources confirm however that illegal logging and trade is finishing off the remaining sandalwood on the island, just as in Timor (McWilliam 2001).

From the Sumbanese perspective, the best type of employment with regard to status and monetary income, and the common goal of pupils starting their education, is to be a civil servant. The riots in 1998 in Waikabubak, discussed next in Chapter VI, were triggered by demonstrations against the district government, which was accused of fraud and nepotism related to the results of exams for potential civil servants. According to official government statistics $^{14}$ there are 1658 official civil servants in West Sumba, and another 3205 people who work as schoolteachers. The total of people who work for the government is about 5000, which is 25 per cent of those employed outside of agriculture in West Sumba. This figure does not include people who work indirectly for the government or are employed by government officials, such as their drivers, housekeepers, guards and cooks. The figures only include persons who are government-employed themselves, and not those who share their household. If we were to estimate the number of people whose livelihood depends largely

12 BPS Statistics Indonesia at http://www.bps.go.id/sector/nra/grdp/table4.shtml (accessed 5-8-2004).

13 Shellac is a secretion of the lac insect Coccus lacca, and it is a material used as component for paint.

$14 \quad$ Sumba Barat dalam angka 2002. 
on income from government employment, we need to multiply 5000 many times. The only other sector in which people on Sumba earn a good (monetary) income is trade. This sector on Sumba is completely dominated by Sumbanese of Chinese ethnic origin. Table 2.4 depicts the structure of the economy in West Sumba according to official state statistics:

Table 2.4. West Sumba's Gross Domestic Product 2001 and its division over the major sectors of the district economy.

\begin{tabular}{|l|c|c|}
\hline Indicator, for West Sumba 2001 & $\begin{array}{l}\text { In billion } \\
\text { rupiah }\end{array}$ & $\begin{array}{l}\text { As percentage of } \\
\text { District GDP in } \\
2001\end{array}$ \\
\hline $\begin{array}{l}\text { Gross Domestic product (current market } \\
\text { prices) }\end{array}$ & 482 & 100 \\
\hline Government expenditures & 78 & 17 \\
\hline GDP produced in agriculture, of which: & & \\
a food crops' contribution to GDP & 194 & 42 \\
b horticulture & 34 & 7 \\
c forestry & 0.8 & 0 \\
d livestock & 50 & 11 \\
e fishery & & 1 \\
Total & 284 & 61 \\
\hline GDP produced in: & & \\
a trade & 14 & 9 \\
b tourism & 1 & 0 \\
c mining & 2 & 1 \\
d industry & 3.5 & 2 \\
e building and construction & 7 & 4 \\
f banking and finance & 6 & 3 \\
g transport and communication & 8 & 3 \\
\hline
\end{tabular}

By far the largest employment sector is agriculture. In terms of the daily activities of the population, $87 \%$ of the economically active population works in agriculture. This figure includes well-educated people who have not succeeded in finding a job corresponding with their education, which constitute a hidden yet politically important category. The agricultural sector accounts for $61 \%$ of the District Gross Domestic Product. Moreover, $42 \%$ of the GDP is produced in food agriculture. The latter figure is highly fictive because a large part of food production is subsistence agriculture, which means that only a small part of the harvest is sold, whereas the bulk of it is kept for consumption or enters the barter economy, where food is exchanged for services. The 
government is also much more dominant in the district monetary economy than these official figures suggest. The routine government expenditure by itself accounts for 16 per cent of GDP. The district government is the employer of the official civil servants and of numerous other employees with minor status. It is also the institution that issues infrastructure-related projects. The districts government has obtained more than $90 \%$ of its own revenues from the central government since 2001, through the General Allocation Fund (Dana Alokasi Umum, DAU). ${ }^{15}$ Table 8.1 in Chapter VIII presents figures for the government budget from 2000 until 2005.

\section{Social cleavage}

The statistics in this chapter already hint at the type of social cleavage which exists on Sumba. The percentage of the working population of West Sumba for whom 'agriculture' was main economic activity was $87 \%$ in 2001. Although, according to government statistics, the share of the agricultural sector in West Sumba's GDP is $61 \%$, this does not mean that the division of income or wealth is likewise. Although I have no hard evidence, I am convinced that the figures about agricultural production are estimations of harvested quantities multiplied by standard selling prices, whereas in reality in the rural areas people use a large proportion of the products for own consumption, and sell only their surplus.

If we do not look at statistics, but travel around in West Sumba, it is clear that the rural population, living off the main road, is poor. Along the main road and especially in the capital town Waikabubak there are some relatively rich people. The urban population speaks Indonesian, watches TV, uses mobile phones if they can afford them, and communicates frequently with people outside Sumba. The rural population mostly uses the vernacular language and rarely watches TV, and their lives are more concentrated around their villages. But the rural youth try to participate in the urban experience.

Social cleavage in West Sumba is not an urban-rural division in a strict geographical sense. The term 'urban' as used here refers to a complex of linked characteristics: modern, involved in monetary economy, Indonesian, and literate. Any person on Sumba who aspires to inclusion in this urban group should have good links with the state, preferably by getting a government job himself. Obviously the highest concentration of 'urban' people live in the capital Waikabubak. There are also 'rural' people living in town, for example some of those who were born in the ancient kampongs of 
Waikabubak and kept their rural way of life. Unmarried youth from the rural areas are trying to become part of the urban setting. They come to town to go to school, provide domestic help in their boarding house, and some of them succeed in finding jobs in shops. The 'urban type of people' outside the capital preferably live close to the main road that connects Waikalo harbour with Waikabubak, Waingapu and Melolo. There, they enjoy electricity and have transport connections to town. Many people with higher state positions have both a house in the capital and a house in their village, with relatives in each house to keep the household running even if the host is absent. The further one travels from the main road, the sparser 'urban' characteristics become, for example, the rural schools have only a few teachers, the village heads speak vernacular most of the time, and there are no shops. The poorest people have no links with the urban area: they have no one to stay with if they go to town, they cannot afford the transport, and they are busy working on the land.

Chapter I introduced the political model of stratification that focuses on the role individuals in the political process, and the capacity they have to appropriate part of the state's resources. The division in political class, political public and tani-class is an alternative way of analyzing social cleavage in Sumba. The top layer of society and the central part of this model, the political class, consist of people who derive their revenues and income primarily from the state, through formal salaries from the offices they occupy, though projects they implement as commissioned by the government, or through informal means connected to public offices, such as, bribery, mark up, rent or corruption.

Civil servants, politicians and contractors are the core of the political class. Most of them reside in the capital Waikabubak, because it is the bureaucratic centre of West Sumba. The town is the seat of Central Government civil servants and the District Departments (Dinas). Central government civil servants are those who work for the National Family Planning Coordinating Agency (BKKBN), the Department of Religion, the State Court of Justice, the Public Prosecutor and the Central Statistics Office. Many of them are not Sumbanese. In 2002, 6.2 per cent of the population of West Sumba (23,000 people) resided in the capital Waikabubak. Yet, 38 per cent of the civil servants and teachers were based in the capital. Since the type of civil servant positions in town are the higher ranked, not only in numbers of officials but also in terms of power, Waikabubak is the centre of West Sumba's political class.

Of the large and medium scale trade companies active in West Sumba, 80 per cent are located in Waikabubak. According to the data of the Central Statistics Office, 50 of the 83 traders who are involved in trade with other islands, reside in Waikabubak whereas the others have their premises along the road to the harbour Waikalo. Of these traders, 72 per cent are labelled 'for- 
Table 2.5. Number of civil servants and teachers in 2002 in West Sumba, in Waikabubak and outside the capital.

\begin{tabular}{|c|c|c|c|}
\hline $\begin{array}{l}\text { Location } \\
\text { Type of government employees }\end{array}$ & $\begin{array}{l}\text { Waikabubak } \\
\text { (District } \\
\text { capital) }\end{array}$ & $\begin{array}{l}\text { Outside } \\
\text { the capital }\end{array}$ & Total \\
\hline Central government civil servants & 172 & 0 & 172 \\
\hline $\begin{array}{l}\text { Local government civil servants at } \\
\text { District Departments }\end{array}$ & 1184 & 0 & 1184 \\
\hline $\begin{array}{l}\text { Local government civil servants at } \\
\text { sub-district level }\end{array}$ & 8 & 207 & 215 \\
\hline $\begin{array}{l}\text { Local government civil servants at } \\
\text { village level }\end{array}$ & 15 & 72 & 87 \\
\hline Primary school teachers & 168 & 1939 & 2107 \\
\hline $\begin{array}{l}\text { Teachers in secondary and higher } \\
\text { school }\end{array}$ & 315 & 783 & 1098 \\
\hline Total & $\begin{array}{r}1862 \\
(38 \%)\end{array}$ & $\begin{array}{r}3001 \\
(62 \%)\end{array}$ & $\begin{array}{r}4863 \\
(100 \%)\end{array}$ \\
\hline
\end{tabular}

Source: Sumba Barat dalam angka 2002, Badan Pusat Statistik, Kabupaten Sumba Barat, Province NTT

eign', which means Chinese in this case. They are in control of various sectors in the Sumbanese economy: trade, transport and construction. There are no reliable figures publicly available to measure their role in the economy, but if the contribution of these three sectors to the GDP of West Sumba is taken as a very rough and speculative indicator of their official turnover, they account for at least $20 \%$ of the district's GDP.

The role of businessmen in politics is even harder to assess. Contractors need the support of those who can decide about the allocation of the district budget. This budget is used partly for the projects that contractors compete for. Politicians and bureaucrats who influence how the money is spent receive a percentage of the total project budget. In times of elections politicians clearly rely very much on support from businessmen: they provide transport, food and money to facilitate election rallies, as will be discussed in Chapter IX. The mutual dependency between businessmen and politicians and bureaucrats strengthens the cohesion within the political class. 